\title{
The Judicial Interpretation of Syariah and Civil Court for Non-Muslim Transgender
}

Muhamad Sa'dan Abdul Aziz, Hazhari Ismail, Jaffary Awang, Nur Farhana Abdul Rahman, Mohd Izwan Mohd Yusof

To Link this Article: http://dx.doi.org/10.6007/IJARBSS/v11-i6/10103

DOI:10.6007/IJARBSS/v11-i6/10103

Received: 12 April 2021, Revised: 14 May 2021, Accepted: 28 May 2021

Published Online: 10 June 2021

In-Text Citation: (Aziz et al., 2021)

To Cite this Article: Aziz, M. S. A., Ismail, H., Awang, J., Rahman, N. F. A., \& Yusof, M. I. M. (2021). The Judicial Interpretation of Syariah and Civil Court for Non-Muslim Transgender. International Journal of Academic Research in Business and Social Sciences, 11(6), 135-151.

Copyright: (c) 2021 The Author(s)

Published by Human Resource Management Academic Research Society (www.hrmars.com)

This article is published under the Creative Commons Attribution (CC BY 4.0) license. Anyone may reproduce, distribute, translate and create derivative works of this article (for both commercial and non-commercial purposes), subject to full attribution to the original publication and authors. The full terms of this license may be seen at: http://creativecommons.org/licences/by/4.0/legalcode

Vol. 11, No. 6, 2021, Pg. 135 - 151

Full Terms \& Conditions of access and use can be found at http://hrmars.com/index.php/pages/detail/publication-ethics 


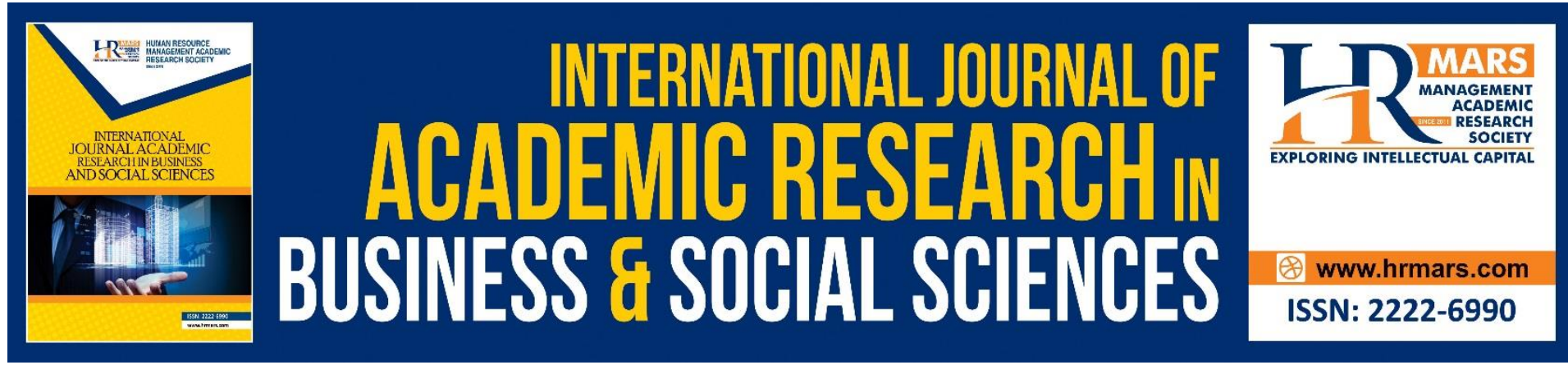

\title{
The Judicial Interpretation of Syariah and Civil Court for Non-Muslim Transgender
}

\author{
Muhamad Sa'dan Abdul Aziz \\ Faculty of Islamic Studies, National University of Malaysia \\ Email: saqdan910@gmail.com
}

Hazhari Ismail

Department in Early Childhood Education, Faculty of Human Development, Universiti

Pendidikan Sultan Idris

Email: hazhari@fpm.upsi.edu.my

\begin{abstract}
Jaffary Awang, Nur Farhana Abdul Rahman
Department of Theology and Philosophy, Faculty of Islamic Studies, National University of Malaysia

Email: jaffary@ukm.edu.my,nfarhana@ukm.edu.my
\end{abstract}

Mohd Izwan Mohd Yusof

Division of Family Development, Social and Community, Department of Islamic

Development (JAKIM)

Email: izwanyusof@islam.gov.my

\begin{abstract}
The life of non-Muslim transgender is influenced by the views on sexual minority act or actions of various religions. This work will examine the problems facing by transgender among Hindu and Buddhist followers in Malaysia within a civil law. On top of that, this work also examined the Muslim transgender case heard at Syariah court law. The work underlined the need for non-Muslim transgender to have the cases in the civil court. In addition, western ideologies have also motivated non-Muslim transgender to legalize transgender as a third gender identity in Malaysia. In addition, in Syariah court jurisdiction, non-Muslim transgender was not affected. This research also suggested that Article 121(1A) prevail, upholding the both Civil court and Syariah courts; two different jurisdictions. The future work will be focused on non-Muslim LGBT identities and religious beliefs.
\end{abstract}

Keywords: Transgender, Syariah Court, Civil Court, Non-Muslim, Buddhist, Hindu.

\section{Introduction}

Transgender lives have often been arguable matters, particularly as it concerns the beliefs of faith that it is either acceptable or forbidden. In general context, Sumerau et al. (2018) in Cragun and Sumerau (2015), transgender people were the least favourable in the United 
States of America compared with other populations. The transgender population was divided into four races in Malaysia, the percentages of Malay is $50.7 \%$, Chinese $27.5 \%$ followed by Indian 7.8\% and others 14\% (Department of Statistics Malaysia, 1995). However, Baeur et al. (2017) argue where transgender is permissible within a culture to certify inclusiveness in any way. In all religions such as Islam, Judaism, Hinduism, Christianity the transgender issues are associated with the world view. Nevertheless, Savinder and Nirmala (2010) explain that Hindhu followers have been identified in Malaysia as Hindus, Sikhs and Christians. In Malaysia, however, Buddhist followers have been identified as Buddhists, Christians, Taoists or Confucians as Chee (1983) explained.

According to Devdutt (2001), it states that homosexuality has been accepted but is not a part of the mainstream of Hinduism. Nevertheless, for some castes such as Brahman, homosexuality was also not allowed but it accepted among other castes. However, Pande (2008) states that their God Shiva is also associated with Ardhanarishvara which is a malefemale combination. In Buddhism, on the other hand, where 14th Dalai Lama (1996) stressed that the relationship of homosexuality, whether in men or women, is improper act or conduct. Nydahi (2006) believed that one of the Buddhist scholars that sexual orientation is not significant as a Buddhism. So, it can be clearly concluded there are debates amongst the Hindu and Buddhism followers.

In addition, in some of Hindu and Buddhism modern views and definitions of transgenderism are more accepted. In Scherer's (2006) study, which distinguishes the Buddhist standpoint on issues of sexualities between same sex and sexual differences including non-binary and gender identities crisis. Given the origins a patriarchal society in Buddha, they also supported each gender on the potential to grasp enlightenment, looking themselves inside the Lotus Sutra, one of the most important in texts of Buddhism. There are three principal branches of their religion in Buddhism: theravada (the instruction of the elders), Mahayana (the great vehicle) and vajrayana (the thunderbolt vehicle). As explained by Mathews (nd), the sexual orientation has been classified into male (bhatobyanjuanaka) or interpreted into hermaphrodite and female (pandaka) or also known as confusing gender.

As for Hinduism, Mishra (2013) clarifies the idea of samskara as a way of strongly achieving or understanding oneself. There are four basic concepts in Hinduism: artha (values economy), dharma (righteousness), kama (pleasure), and moksha (liberation). Khushboo (2017) categorizes it into five common groups as far as gender identity is concerned: Kothi (representing themselves as men); Hijras (biological male but denying the male personality), Aravanis (woman covered in the male body), Jogappa (who is the Renukha Devi's goddess' servant), Shiv-shaktis (male but women). In primeval astrology, Hindu law, medicine and linguistic science the third sex was created.

The Hindu legislation (200 BC-200 AD) shows three sexes in biological form; male, female and third sex in the study conducted by Michelraj (2015). In addition, Patanjalis states that the Mahabhaya (200 BC) derives from three natural genres, the works marked by the Indian linguist (Michelraj, 2015:12). The three genders in Vedic astrology are related with Mercury, Saturn and Ketu. Moreover, Michelraj (2015: 12) has mentioned that in Purano, three sorts of Music and Dancing devas: apsaras (female), gandharvas (male), and kinnars (neuter) are associated with Mercury and Saturn and (especially) Ketu.

In a study performed by Michelraj (2015), the Manu Smriti which the Hindu law (200 BC-200 AD) exemplifies three sexes in biological form; male, female and third sex. Furthermore, one of the works scripted by an Indian linguist, Patanjalis notes that the Mahabhaya (200 BC) derives from three usual genders (Michelraj, 2015:12). In Vedic 
astrology, "the nine planets are each ascribed to one of the three sexes; the third gender, tritiya-prakrti, is associated with Mercury, Saturn and (especially) Ketu. Additionally, Michelraj (2015:12) stated there are references in Puranas to three types of music and dancing devas: apsaras (female), gandharvas (male), and kinnars (neuter).

On this research, it will focus on evaluation of non-Muslim transgender experience in Malaysia. In addition, the non-Muslim transgender experience as a minority group will be interpreted based on Syariah and Civil courts.

\section{Hindu and Buddhist transgender activists with a socio-cultural background in Malaysia}

It seems that belief is a guide to the future of any human being. Socio-cultural context emphasizes the viewpoints of the activist among Buddhist and Hindu transgender. This could simply be defined by personal experience basis of a transgender non-Muslim activist living in Malaysia who rules Islamic law. While non-Muslim transgender is not abided according to the rules of Sharia law, also it is affected because Malaysia's refuse to recognize transgender completely as a third sex. Faced with numerous obstacles and difficulties, non-Muslims transgender made (Hindus and Buddhists), stood up and some of them became activists of transgender and shared their experiences.

\section{Renowned of Hindu's Transgender Activists}

In Malaysia, some Hindu transgender groups still believe in their teaching of religion. It is confirmed by research carried out by Shuyashini (2014), there is Hindu's temple in Pandamaran, Klang, Selangor which belonged to the transgender community. As a matter of fact, transgender is a recognizable group, for example the Indian transgender icon normally referred to as "Asha Amma," or "Chow Kit Indian godmother" (Shuyashini, 2014). Asha became an icon and role model for the Indian transgender community because, while she was a transgender woman, she obtained her Malaysian National Registration Identity Card as a woman. Additionally, there are two famous Hindu transgender activists in Malaysia commonly known as Dorian Wilde, a transgender man and Sharan Suresh, a transgender woman.

In the first place, Sharan Suresh at the Pink Triangle Foundation represented Male and Transgender Sexual Health (ISEAN) as an advocate and policy advocate for the Southeast Asian Islands Network. Sharan, on the other hand, looked more woman than her given gender, born as a male. Her story started at the age of 14 , when she was sexually assaulted in school. Sharan added that she had been born as the oldest in her family, so no parents were going to teach their children how to act like the opposite. She made a big decision when Sharan reached the age of 21 and started leaving her house after her family refused her choice to become a woman. Additionally, Sharan was finally wedded and plans to adopt a child along with her boyfriend (Samantha, 2014). In addition, in Malaysia, the non-Muslim transgender is also not permitted to get married because they cannot only change the gender indication in the identity card that is beyond the control of the National Registration Department. However, some Malaysians have always found same-sex marriage to be a cultural taboo and against other cultures and religions.

Second, Dorian Wilde is one of the founders and one of the LGBT activists of Transgendermen from Malaysia in 2012. He was raised in a Penang family as a female and found him trapped in an incorrect body. Dorian is the Sexual Orientation and Gender Identity (SOGI) representative with emphasis on transgender rights in Malaysia. Transgendermen of Malaysia (ToM) was not only commanded by him as one of the Malaysian virtual groups of 
transgender people. Dorian's life story started at the age of three. He believed he was a child who, at the age of 17, was stuck in the body of a girl and transferred to Singapore. Dorian is involved in the transgender network in Malaysia and the Transgender Sexual Network.

Having travelled to Singapore, he had succeeded in meeting a transgender man in Singapore. He named the guy his mentor who gave him faith, support and inspiration in LGBT community. As a Malaysian, Dorian noticed that in her own country, the LGBT group was being oppressed. Far too much force had been exerted; he chose to move to Kuala Lumpur, becoming an influential right-wing LGBT activist. He actively supports and protects transgender peoples' rights in Malaysia today. Sharan and Dorian may be assumed to be Hindu supporters who argue that in Malaysia transgender should be treated fairly.

\section{Renowned of Buddhist's Transgender Activists}

The Buddhist follower also faces difficulties and problems in Malaysia. First Dr. Jessie Chung is a Leader of the Natural Health Farm and Vice-President of the Malaysian Anti-Cancer Association (MACA). Born in 2003 in Sarawak, she was active in changing genders. In addition, her academic success was exceptional. She holds a Ph.D. in Oncology of Clinical Medicine from the University of Chinese Medicine in Guangzhou and is accredited in Malaysia as a Chinese traditional practitioner (Samantha, 2014). On 12 November 2005, Dr. Jessie Chung married Joshua Beh in solidarity with her transgender life and her experiences which was assumed to be Malaysia's first same-sex marriage. Chung was a Chinese transgender and she married Beh in Kuching, Sarawak (KRYSS, 2014). The authorities in Malaysia declined to the union, but three pastors arranged a ceremony before almost in front of 800 audiences. In a Borneo's 2016 post online stated that Chung and Beh's wedding under Malaysian law was not accepted.

Second, Yuki Vivienne Choe or Yuki was born from Ipoh's Transgender activists and founder, one of Transgender Malaysia's. Yuki is a transgender and feminist who from a distance observed both the LGBT and former homosexual movements. Not only that, Yuki also wrote and considered herself as a genuine woman-born transgender on the basis of her observations for various webzines and newspapers. As a key factor it still prevails over the person homosexual the same equality and rights of all gender styles. Yuki is also one of Malaysia's most popular transgender advocates, where she works for Tilted Nation (LGBT), a project in Malaysia and US-based Ex-Gay Watch for LGBT communities. Yuki also runs Transgender Malaysia, a community which supports transgender Malaysians and their family and friends. Dr. Jessie Chung and Yuki are now prominent Buddhist activists in Malaysia playing captivating responsibilities within the community.

\section{Hindu's Transgender Experiences in Malaysia}

In the viewpoint of Malaysia, Hindu transgender also has its experiences in the context of Islamic community in Malaysia. As Malaysia is a Muslim-majority country, the non-Muslim transgender cannot abide by the Sharia law. They would also be charged under the Minority Crime Act 1955 for the non-Muslim transgender act or actions. Examples of Hindu transgender experiences could be provided by responding to the interview sessions conducted by previous scholars, researchers and studies as follows:

In December 2011, Sharan is a Transgender Indian woman, staying at Kuala Lumpur. At that time, she was abducted by a man who was pulling his car down the Chow Kit lane. At the time in his car the man talked to her asking Sharan for help in getting a transgender woman to get some sex services. The guy immediately locked the doors and picked her up 
from Kuala Lumpur. Without hesitation Sharan asked the man where they were headed. That man replied that 13 guys are waiting for Sharan to take away her body. They were starving just for sex and have killed seven Malaysians ethnic and Sharan is their first Indian. In this case, Sharan was an Indian transgender woman who was oppressed by communities for her gender identity. Four informants anonymously referred to as $\mathrm{P}, \mathrm{K}, \mathrm{S}$ and $\mathrm{M}$ (not real names) will further clarify another trans-sexual and transvestite past in the Indian community as follows:

Second, $\mathrm{P}$ is a transsexual working at a flower store, Kedah's Kulim. She loved an Indian man and in 2013 she decided to get married. P has a godmother who guided her to become a transvestite in Thailand and then to have a sex-change operation. But she was crowned Miss Kulim in 2010. He hoped that after surgery for sex operations, the government would recognize transgender identities (Shuhasyini, 2014). Secondly, K, born in Taiping, Perak, as transsexual. She worked in a bridal shop and sells flowers in which her principal income is prostitution. In Thailand, she was subject to sexual surgery. $K$ had also fought and moved out from her family.

Thirdly, $\mathrm{S}$ was born as a transvestite in Klang, Selangor. She worked as a cashier in a supermarket after finishing her high school. She assumed that she was the only transgender, although there were a lot of them. S's idea to become a woman in the future and she wanted to further the studies after the operation had been done. She had no boyfriend and she did not engage in prostitution and therefore she did not want a transgender group to be feeling embarrassed (Shuhasyini, 2014). Fourthly, M lives in Seberang Jaya, Penang and she is twenty-five years. $M$ also planned to marry Saravanan, his husband, who was a sales assistant. $M$ will participate every year in the festival organized by the transgender community in Pandamaran's temple Klang (Shuhasyini, 2014).

Based on the five Indian informers, namelessly identified as Sharan, P, K, S and $M$, most of respondent illustrated that they need a husband-wife spousal relationship. A Hindu transgender follower, as in Thailand and Singapore, is unable to have the same sex marriage even though they have been subjected to sex reassignment operations outside of Malaysia. This is because Malaysia does not even accept same sex marriage. Non-Muslim transgender, however, does not abide by shari'a law and regulations. But it can commonly be clarified that only Section 21 of the Minor Offence Act of 1955 can fine Hindu followers in Malaysia and not Sharia law itself.

\section{Malaysian's Buddhist Experiences in Malaysia}

There are also many challenges and issues facing the Buddhist transgender community in the majority of the Muslim population. In Malaysia, Chinese followers can be identified as Buddhists, Taoists and Confucians (Chee, 1983). If the non-Muslims do not abide the rule of Sharia law, they will be punished for cross-dressing under the Minority Offense Act of 1955. It listed drunkenness and disorder in public places, for instance under section 21 . The nonMuslim transgender is caught and fined during the raid by the religious officer. The case of Buddhist transgender followers in a civil court may be demonstrated Young people through safer spaces (KRYSS). The KRYSS is an NGO founded in 2003. The International Child Rights Network (CRIN) is also a member of this organization. The group seeks to foster equality between women and men and to protect women's rights. There should be a greater awareness of gender inequality and abuse between men and women. This NGO performs an interview in $\mathbf{2 0 0 9}$ with a raid on sexuality in Johor as follows: 
In 2009 they raided a nightclub in Johor where Non-Muslim transgender women are also trapped in the Religious Department when they are arrested. According to Aisah, they had detained 76 transgender people. All transgender women were armed and put into lock up in the Department of Religion. When they look at the ID card, it is very difficult to recognize transgender ethnicity. Following, the religious officer let Indians and Chinese ethnic free to go but still one of the transgender Chinese was cried It's not fair. She said, "I am not a Muslim. She said, How are you able to arrest me (KRYSS, 2014).

Established on the above case, it is evidently clarified that through the raid carried out by religious officials, non-Muslims were also involved. As explained earlier, the Islamic religious officer cannot identify on every single non-Muslim transgender based on their identification card. Section 28, according to Johore's Syariah Criminal Offenses Enactment (1997), stresses any male person who wears and stances in a woman's dress in any open area. This section states that they are guilty of any crime and are responsible for a fine not above than 1,000 ringgit or sentence for a period not more than one year or both.

However, this Syariah criminal law only applies to Muslims, but in general they would be prosecuted for non-Muslim followers under Section 21 of the 1955 Minor Offence Act. It is difficult for the religious officer to distinguish between Muslim and non-Muslim during the raid to transgender community unless they show their ID card. This is to show that transgender identities are either male or female because they cannot easily change the gender marker because it needs to be related with their birth certificate. Besides that, the experiences of the transgender of Buddhist follower can also be addressed further in the civil court cases. In a case of Wong Chiou Yong, vs Pendaftar Besar/Ketua Pengarah Jabatan Pendaftaran Negara [2004] 3 MLRH 127, the civil court interpretation of Wong's case can be summarised as below:

On 8 April 2002, Wong Chiou Yong had been subjected to sex reassignment operations from female to male. He requested in his application to have his birth certificate and the national identification card for the registration was amended. However, the claimant's demand has been dismissed by High Court. Wong submitted the original submission to the General Registry of Births and Death by pointing out an error in the record book entry and refused to do so. In addition, the judge argued that those who had experienced a sex change operation after reassignment surgery cannot be considered to belong to sex. The High Court relied on the provisions of the Births and Deaths Registration Act 1957 and the National Registration Act 1959, stipulating that a reasonable judgment in regard to that petition would clash with the legislature's spirit and purpose reflected in that legislation, and that it was a concern for Parliament rather than for the courts.

In Interpreting the case of Wong, Malaysia's National Registration Department plays an interesting role in deciding and recognizing the gender of someone. As can be argued, in Malaysia, the Federal Constitution is the authority in any situation. There are many articles and laws which protect a person's freedom. She had applied for a name change after she returned from sex surgery in 1996 and it was granted. Nonetheless, the last four digits remained in the identity card, and this would be an obstacle to getting married to his wife. In this case, Wong argues that his right to change his ID digit was violated in Malaysian Federal Constitution under Article 5 (Personal Liberty) and Article 8 (Equality).

In the case of Wong, his application was rejected because of the psychological sex that does not come under any of these four criteria; chromosomal, gonadal, genital and psychological factors. Nevertheless, as followers of Buddhism, he has not been bound with gazetted fatwa on a person who is born female remains as a female while through operation 
he has successfully transformed into female. If Malaysia's National Registration Department approved the gender change, names, last four digits to the non-Muslim followers, Muslim transgender would also assert their rights regardless of whether or not they had violated Sharia law.

The civil court held acceptance of the appeal. This could be clarified that, under the Birth and Deaths Registration Act 1957, no mention is made of the right to change a gender sector. Nonetheless, the 1959 National Registration Act authorized the correction but it depends on how the court interprets that a transgender should alter their name or gender markers. Dato's James Foong, of Kuala Lumpur High Court, retained the reason for this case. It's not about changing the name and gender, as all applications have to go through court processes to allow the discretion of judges to administrative officers over the identity of transgender people.

The civil court ruled acceptance of the appeal. It can be clarified that, under the Birth and Deaths Registration Act 1957, no mention is made of the right to alter a gender marker. Nevertheless, the change was approved under the 1959 National Registration Act. If a transgender should change its name or the symbol of the gender, depends on the view of the court. Dato's James Foong, of Kuala Lumpur High Court, retained the reason for this case. This is not about changing the name and gender, as all applications have to go through court processes to allow the discretion of judges to administrative officers over the identity of transgender people. J.G was active in changing its name to an identity card as set out in Regulation 14. Hence, she successfully applied to change her gender to female from male.

However, the jurisdiction of the court was different in both Wong and J.G cases. This can be clarified that the birth certificate of the person will be vital even though the person has undergone any surgery for sex reassignment and genital changes. In the case of J.G, the court has the right under the 1950 Special Relief Act to grant the jurisdiction. In addition, section 6(2) of the National Registration Act 1959 allowed J.G's application to make an amendment and adjustment in the register and identification card. The defendant was ordered to change the last digit of the identification card of the Plaintiff, J.G to represent the reassigned gender. On the other hand, the claim was dismissed in a Wong's case, and it should be taken to Parliament rather than the courts. It can be contrasted that the rulings were different in both cases where the courts heard in a civil court. It can be claimed that various definitions and judgments against non-Muslim transgender is carried out in a civil court.

\section{Embedded conflict of Non-Muslim Transgender}

Non-Muslim transgender (Hindu and Buddhist followers) fight for their rights and some in the ID succeed in modifying their remarks about gender. In addition, the Hindu and Buddhist traditions play an interesting role for their adherents as well. The transgender communities also believed in the existence of the religious guidelines, laws, and pathways. In the understanding of modern Buddhism, Vermeulen (2016) describes to follow the dharma by agreeing to certain Buddhist teaching on sexual diversity. In comparison, Buck (2004) states that Hinduism historically is against homosexuality. Due of multicultural and multi-religion, Muslim transgender also sought their rights as well as non-Muslim. It can be deduced that there is embedded conflict between non-Muslim and Muslim transgender in Malaysia.

In Malaysia, transgenderism among Hindu and Buddhist followers can commonly be defined as unusual in terms of their gender identity and speech. It can be exemplified in a research written by (Abdul Aziz \& Ismail, 2020), which established the Malaysian Consultative Council of Buddhism, Christianity, Hinduism, Sikhism, and Taoism (MCCBCHST) in 1983 as an 
organization for interfaith dialogue. MCCBCHST can be found on their website called Harmony Malaysia, and it consisted of many Buddhist and Hindu NGOs. The Buddhist followers included the Sasana Abhiwurdhi Wardhana Society (SAW), the Malaysian Buddhist Association (MBA) and the Buddhist Missionary Society of Malaysia (BMSM) for Buddhist followers.

On the other hand, Malaysia Hindu Sangam (MHS) is for Hindu followers. MCCBCHST covers lesbian, gay, bisexual or transgender (LGBT) groups from all such abuse, threats, aggression and others (Goh, 2014). It is because non-Muslim groups often tried to legalize LGBT rights from the Muslim community, which opposed the view of Islamic religion itself. Thus, it can be concluded that non-Muslim transgender should embed the conflict they face through MCCBCHST because the group was removed from Islamic NGO after having held numerous meetings and debates.

A story of Suvati, a 24-year-old transgender woman in Kuala Lumpur explain some challenges faced by Buddhist and Hindu followers. Suvati had faced many discriminations by her prospective employer based on the Human Rights Watch's interview (Human Rights Watch, January 2014). During the interview session, while she's standing on her gender identity, several employers have called the police. She was also attending a work interview in another instance at a foreign call center. The interviewer learned at that time that she was transgender and was mocked by naming her sissy (pondan) and transgender people should be curse.

In another instance, A police officer sexually harassed Chunhua by arresting her while they were conducting drug checks in 2013. Chunhua is a Kuantan transgender woman, aged 27. When police stopped and left, it occurred several times in Kuantan, and requested that they take urine samples on the spot. Police had the chance to abuse and humiliate them according to Chunhua. Not only had this, the police asked her on many occasions to show off her private parts in a car park. At the time, Chunhua was clothed in women's clothes and they requested to see her penis, stating her penis was very large (Human Rights Watch, January 2014).

Ann is a transgender Indian woman and twenty years old. Ann shared her experiences with family members, and her father in particular. Since she was an infant, her father had physically abused her, because she looked like a girl even as a kid. The dad even told other family members to treat her badly. Reflecting that, her feminine characteristics were shown to Ann and she took comfort in playing conventional female roles (KRYSS interview, November 2010). On the other hand, Emilia is a Chinese transgender 24-year-old woman who binds her breasts whenever she attends a family function so as not to attract attention to herself (KRYSS interview, 2011).

Dorian, as a transgender man where he recalled hearing something cruel to him as his father said. The father said "You obey my rules; this is my home. I just don't embrace it all. If you really want to be this way, then you should go. I am going to help you pack and I'm going to lock the door behind you "(Human Rights Watch, January 2014). The family itself was not able to recognize their children who were transgendered and it was something odd. In addition, Lam Cheong is a 51-year-old transgender man, recalled as a student during his difficulties. He was met in school with his peers and expected to abide by social gender standards. He noted that he was born as a woman but clearly, he did not feel confident wear a girl's dress such as skirt and dress (Interview by KRYSS, 2011). 


\section{Constructing the boundaries between Muslim and non-Muslim Transgender based on judicial interpretation of Syariah and Civil court}

Islam is a religion of federation, according to Article 3 of the Federal Constitution of Malaysia. Article 11 stated, however, that religion other than Islam should practice its religions in harmony and peach. Malay transgender in this sense, abide by the fatwa issued where any form of transgender cross dressing and male to female or vice versa are prohibited. There are three conditions to be addressed about non-Muslim issues in Malaysia. There are case of Muhamad Juzaili Bin Mohd Khamis v. Negeri Sembilan State Government, 1955, Gender reassignment surgery fatwa, and Minor Offence Act. The Muslim-Non-Muslim transgender boundaries can be clarified as follows:

\section{Muhamad Juzaili Bin Mohd Khamis v. State Government of Negeri Sembilan}

Negeri Sembilan's case in 2011 has a stronger effect after years of hardships on the transgender communities. The choice is not only available to Muslim transgender but also to non-Muslims as well. The fact that this case involved three Muslim men; Muhammad Juzaili bin Mohd Khamis, Shukur bin Jani, and Wan Fairol bin Wan Ismail have pursued a clarification due to where they have Gender Identity Disorder (GID). It was mentioned in section 66 of the 1992 Syariah Criminal Enactment. The respondent has taken up the case to the Court of Appeal in 2014 after the case was rejected for judicial review in 2012. The respondents have verified it that GID is an unchangeable indicator. It would cause them more harm and it would seem wrong to punish them for cross dressing. The appeals court's opinion can be summed up as follows:

In accordance with Article 5(1) of the Federal Constitution, it states that "no person shall be deprived of his life and personal liberty shall be saved in accordance with the law." Moreover, Article 5 was violated by Section 66 and was unconstitutional. It can also be clarified that this transgender's right to life has included livelihood and quality of life. This can be exemplified that transgender would be prosecuted if cross dressing in public space and Section 66 has been seen as violating the wellbeing of the appellants. In addition, Article 8(1) and (2) states that "all persons are equal before the law and have the right to equal protection of the law." It is important to clarify in relation to this article that Muslim transgender who suffered from GID was not equivalent to Muslim non-GID. The court thus considered Section 66 was again in accordance with Article 8. While referring to Article $8(2)$, it has been explicitly clarified that there should be no discrimination expressly on the grounds of religion, ethnicity, descent and gender.

Nonetheless, the case also concerned the definition of Article 9(2), which assurances freedom of movement. In this regard, the transgender communities are limited in their movement especially in public space as they would be fined for cross dressing under Section 66. In addition, transgender rights were also violated on the basis of Article 10(2) which guarantees freedom of expression and speech. Equality of speech and expression in one type of speech may be interpreted. Section 66 was also unconstitutional, because many clauses of the federal constitution were violated.

The court ruled that it was unconstitutional for men who had a medical condition (GID) to be penalized as women by the Court. Norafifah et al. (2015) has confirmed this by GID as a disease not treated and diagnosed by healthcare professionals. In short, GID is a crucial factor in deciding whether transgender people will act and live as opposites sex in their lives. GID has been recognized as psychological as well as the most severe form of sex reassignment according to Mageswary et al. (2016). Given the above evidence, Muslim transgender in 
Negeri Sembilan is permitted to cross dressing in shared area because section 66 was considered opposite on federal constitution.

\section{The Issuance of Fatwa}

The fatwa has concerned on sexuality between men and women. On the basis of the 4th Muzakarah of the Fatwa Committee, the JAKIM National Council, held from 13 to 14 April 1982, stated that:

- "Sexual change from male to female or vice versa through operation is prohibited by Islamic law".

- "A person who is born male remains a male even though he has successfully changed to female through operation".

- "A person who is born female remains a female even though he has successfully changed to female through operation".

- "For a person who has born as khunsa musykil (intersex) who has two private parts of male and female, it is permitted to undergo operation to retain the most functional private part according to the suitability".

\section{Cited in e-Fatwa Portal (2018)}

Based on the fatwa that was not gazetted in any territory, it has nevertheless transformed either Muslim or non-Muslim life in the transgender communities. The gazetted fatwa would impose the specific state as it will extend sharia matters according to each state. With the presence of this fatwa, there is still no prohibition to sex reassignment surgery in Malaysia for non-Muslim transgender. As in Thailand and Singapore, if they choose to replace their sexual part or have some surgery, they have to have an operation outside Malaysia. Nonetheless, after the non-Muslim transgender successfully underwent the procedure, they also can not alter the gender marker in the identification card. Thus, for those who are transgender in Malaysia, they must usually live together as a husband and wife without a legal document stating their partnership unless the marital is conducted outside Malaysian territory.

\section{Minor Offence Act of 1955}

Reportedly, non-Muslim transgender would be charged under the 1955 Minor Offence Act. Section 21 of this Act deals with disorderly and drunkenness conduct in shared areas.

Any person found to be intoxicated and unable to take care of himself or to be guilty of some riotous, disorderly or indecent behaviour, or persistently solicited or imported for immoral purposes on any public road or in any public place or retreat, or in the immediate vicinity of any court or public office or police station or place of worship, shall be liable to a fine not exceeding twenty-five ringgit or to imprisonment for a term not exceeding fourteen days, and on a second or subsequent conviction to a fine not exceeding one hundred ringgit or to imprisonment for a term not exceeding three months or to both. (cited in Minor Offence Act of 1955).

As far as possible, non-Muslim transgender is exempted from being prosecuted in all of Syariah law court jurisdiction. However, they may be convicted under the criminal code, Section 21 of the Minor Offence Act of 1955. It was reported in an interview conducted by KRYSS in 2014 where it was also impossible to legalize non-Muslim transgender from their existence. Within this act, the penalty can be fined for a maximum of fourteen days as 25 Malaysian ringgit or jail. In addition, any wrongdoer has been convicted of 100 Malaysian 
ringgit, imprisonment for not more than three months, or both, for second or subsequent fines. While this act is enforced in public against drunkenness and disorderly behaviour

In an Asia Pacific Transgender Network (2017) study, non-Muslim transgender also affected as unable to undergo gender affirmation surgery and get legal recognition of gender. However, based on Human Right Watch (2014), a non-Muslim medical institution can still offer the SRS services. But it's difficult for most transgender people to get SRS services in Malaysia, so they can get services in neighbouring countries like Thailand.

\section{Concluding Reflections: Sexual Minorities of Non-Muslim Transgender due to Influences of Western Regulations}

Transgenderism is a global issue worldwide, and it becomes popular when followers of nonMuslims say it was governing because of Islamic countries. The problem would be exceptional in consideration of the third gender identity in an Islamic country based upon their experiences. Tun Dr. Mahathir bin Mohamad, or simply known as Tun $\mathrm{M}$, made his comment on September 21 that Malaysia does not recognize LGBT society and same-sex marriage (Joseph, 2018). He also added that "Though we agree with recommendations made by Suhakam (Malaysian Commission on Human Rights), we must remind them that our value system is not the same as the West "(Joseph, 2018).

Furthermore, since Malaysia is governed by Islamic governance, JAKIM is an Islamic authority that has oversight over Islamic matters. According to Hidir (2018), Mujahid Rawa, who is responsible for Islamic affairs, said, "The issue of LGBT is not one that only affects Muslims, as we must also look at how it affects non-Muslims." He was appointed to the institution of JAKIM as a minister of religious officer. There will be debate dynamics in multicultural, where Malaysia's dual legal system can continually take place and become embedded among Malaysians. If Malaysian non-Muslims do not have a clear understanding of Islamic religion itself, then there will be a continuous conflict in legalising and acknowledging transgender.

Civil court in Malaysia upholds transgender jurisdiction by adopting the cases of Corbett v. Corbett (1970) and Bellinger v. Bellinger (2003). Both cases have been heard and brought in from western countries. The civil court seems to have greater jurisdiction compared with the Syariah court. It may be exemplified where certain western cultures have already penetrated into the Malaysian legal system. The power of western ideologies can be seen in legalizing transgender people in all areas that concentrate on the issue of human rights and their inclusiveness. Malaysia does not comply with universal human rights norms, such as International Covenant on Civil and Political Rights (ICCPR); International Covenant on Economic, Social and Cultural Rights (ICESCR), and the Convention against Torture and Other Cruel, Inhuman or Degrading Treatment or Punishment (CAT).

The western cultures adopted of universal human rights. Yet only the Convention on the Elimination of All Forms of Discrimination against Women (CEDAW) has been ratified by Malaysia. In its General Recommendation No. 28, the UN Committee on the Elimination of Discrimination against Women claimed that it contained the responsibility of the States Parties under Article 2 of the CEDAW. On the other hand, either Muslim or non-Muslim transgender people in Malaysia still find the original gender in their identity card not yet accepted. Nevertheless, western research centres like Human Right Watch (1978), Pew Research Center (2004) and Asia Pacific Transgender Network (2009) played key roles in outdoing LGBT issues. They conducted interviews with LGBT people around the world, and they have released their study to be shared with culture at large. For example, the interview 
session in Malaysia on how western cultures affected the Malaysian thoughts on Muslim and non-Muslim. Some studies have been released, including The Global Divide on Homosexuality: Greater Acceptance in More Secular and Affluent Countries (2013), “I'm Scared to Be a Woman" Human Rights Abuses Against Transgender People in Malaysia (2014) and Elimination of Discrimination against Women 69th pre-sessional working group (2017), Legal Gender Recognition in Malaysia (2017). The institutions, NGOs, activists and public people will use the report to demand the LGBT rights in Malaysia.

The author proposes three approaches relating to non-Muslim transgender in this study. First, more boundaries should be emphasized in the judicial interference between Syariah and the civil court, particularly when dealing with Muslim citizens. Non-Muslim transgender has also claimed to have been influenced by Syariah court interpretation. The definition of the civil court and the Syariah court should not be combined as it has specific decisions between Muslim and non-Muslim. However, Ridhwan (nd) clarified that GID is a part of mental illness accepted by Syariah court. There are also other forms of mental illness; transvestism. sexual masochism, fetishism, voyeurism, paedophilia, frotteurism, exhibitionism, and sex sadism. Thus, for those who are transgender in Malaysia, they must usually live together as a husband and wife without a legal document stating their partnership unless the marital is conducted outside Malaysian territory. The researchers claim that the benchmarking for Muslim transgender from other states in Malaysia would be in the case of Muhamad Juzaili in order to prevail their privileges in transvestites.

Secondly, Article 121(1A) of the Federal Constitution should prevail and there should be no interference brought under Syariah court jurisdiction. The Federal Constitution is a fundamental constitution, and all other laws must adhere to the Constitution. Shanmuga (2017) is a constitutional lawyer in Kuala Lumpur interpreted that Syariah court must not intervene in any cases which non-Muslim is affected. Shanmuga (2017) also pointed out that the Syariah court will deal with a person who professes the religion of Islam in the fields of family law, criminal law and Islamic personal law-making in the State Legislature. Syahredzan (2017) is however a partner of a law firm in Kuala Lumpur and quoted the lecture delivered by former justice Tun Ahmad Fairuz Sheikh Abdul Halim. Tun Ahmad Fairuz delivered his speech entitled "Islam as the law of the land" and any law that contradicted to Islamic scriptures shall be null and void.

The intervention of Article $121(1 \mathrm{~A})$ and its prevalence can be upheld on the Islamic matters that arise upon Muslim transgender. Before the case is brought to the civil court, Islamic law experts should be present to support their evidence, and they refer to the relevant fatwa that has been gazetted on certain matters. However, if the cases involving Muslim are to be heard jointly by the civil court, it must be sitting with the Syariah's judge. Later, they can decide on particular Islamic issues and the decision will bind onto civil court. On top of that, the civil and Syariah courts should be unified at all levels and at the same time federalizing the power of Syariah courts. It can be exemplified that Muslim transgender should be heard the cases and jurisdiction in Syariah court only without intervention of civil court at whole.

Finally, the jurisdiction and decision of the Syariah court should be upheld at all times when Muslim transgender are involved the civil court and the sharia court will both be stricter in treating transgender cases. The civil court, for example, will bring cases involving nonMuslim transgender only and the Sharia court will deal with Muslim transgender. Based on cases in Wong and J.G, it can be clarified that non-Muslim transgender is very progressive and active in the search for transgender acceptance after sex reassignment surgery has been 
performed. For the civil court, it is of the utmost importance that the judgment should be directed merely to the extent that non-Muslims have both genitalia.

The type of khunsa has been divided into two groups in Islam; wadhih (discernible) and musykil (intractable). According to Ibn Qudamah (nd), the determining factor for khunsa will be based on the functioning of a sexual organ in place of which he is urinating. With reference to the court in Syariah, those transgenders who claimed to have been khunsa should bring this matter up to the court in Syariah and should always respect their jurisdiction and judgment.

On Wong Chiou Yong, and J. in a civil trial. G it is possible to deduce that the transgender question is brought to the civil court for a new amendment in the existing law by a non-Muslim transgender (Buddhist and Hindu followers). Nevertheless, in the resolution of the transgender case at civil court the cases of Corbett v. Corbette and Bellinger v. Bellinger have also been a legal precedent. In both cases there are three out of four parameters of the transgender; chromosomal, gonadal (presence, lack of testes or ovaries), genital (including internal sex organs) factor and psychological (Thomson, 1980; Honey, 2005).

Both Syariah and the Civil Court legal proceedings should not be intertwined because they contribute to the interpretation of religion. The presence of third gender was accepted, as previously stated, in Hinduism and Buddhism. Hinduism and Buddhism are a minority group in Malaysia, however, and they have gone through Islamic climate with prevalence of alQuran and as-Sunnah. In summary, the decision on transgender people in Malaysia should be determined by the court definition between Syariah and the Civil Court itself. Furthermore, Malaysian civil court should not use the same authority for Muslim transgender because alQuran and as-Sunnah are prevailed. In Hinduism and Buddhism believers in Malaysia, there is no single codified law, principles, and guidelines on the prohibition of homosexuality amongst LGBT people. If compared to Muslim believer, there are several provisions that clearly prohibited LGBT people to practice their rights. It can be exemplified on every state provisions and fatwa, Muslim transgender facing difficulties to be in opposite genders.

As closing comments, adherents of non-Muslim transgender (Buddhist and Hindu) are not restricted to being legalised in Malaysia's Islamic climate. It can be shown that many cases carry their gender marker in identity card to civil court for adjustment. Behind this, a man would marry a woman in a Malaysian marital structure. A marriage is null if the same gender difference is concerned because Malaysia does not accept and ratify LGBT citizens. However, the dual system which are civil and Syariah court should be thoroughly focused on the religion interpretation of third gender. In future, the research should analyse on Non-Muslim LGBT in Malaysian context which can involve any religion. The research also can focus on the roles of religious approach towards LGBT people in Malaysia.

\section{References}

Abdul Aziz, S., \& Ismail, H. (2020). A Preliminary Study on School Experience and Its Practicality on Islamic Sexual Education for Transgender Children in Malaysia. EDUCATUM Journal of Social Sciences, 6(2), 50-60.

Asia Pacific Transgender Network, SEED Malaysia. (2017). Legal Gender Recognition in Malaysia: A Legal \& Policy Review in the Context of Human Rights. Bangkok: APTN.

Bauer, G. R., Braimoh, J., Scheim, A. I., \& Dharma, C. (2017). Transgender-inclusive measures of sex/gender for population surveys: Mixed-methods evaluation and recommendations. Canadian Institutes of Health Research: Institute of Gender and Health. 
Bowers, R., Minichiello, V., \& Plummer, D. (2010). Religious attitudes, homophobia and professional counseling. Journal of LGBT Issues in Counseling, 4 (2), 70-91.

Brenda L. B., \& Brenda, H. (2015). LGBTQ Experiences with Religion and Spirituality: Occupational Transgenderition and Adaptation. Journal of Occupational Science, 22 (4), 459-476.

Buck, C. (2004). Homosexuality in World Religions. Con Law Seminar Professor Rostorfer.

Charles, L. (1972). The Vimalakirti Nirdes'a Su'tra (Wei Mo Chieh So Shuo Ching). Berkeley: Shambala.

Chee, B. T. (1983). Chinese Religion in Malaysia: A General View. Asian Folklore Studies, 42, 217-252.

Chennery, C. (2016). Transgenderism in Buddhism. UW-Milwaukee Religious Studies Program; Religious Studies Student Organization. University of Wisconsin, Milwaukee.

Cragun, R. T., \& Sumerau, J. E. (2015). "The Last Bastion of Sexual and Gender Prejudice? Sexualities, Race, Gender, Religion, and Spirituality in the Examination of Prejudice toward Sexual and Gender Minorities." Journal of Sex Research, 52 (7), 821-834.

Department of Statistics Malaysia. (1995) General Report of the Population Census, 1991, 1.

Devdutt, P. (2001). Homosexuality in Ancient India.

Dutta, A. (2012). An epistemology of collusion: Hijras, kothis and the historical (dis)continuity of gender/sexual identities in eastern India. Gender \& History, 24, 825-849.

Dutta, A., \& Roy, R. (2014). Decolonizing transgender in India: Some reflections. Transgender Studies Quarterly, 1, 320-337.

Jennifer, L. (2011). 'Borrowing' Religious Identifications: A Study of Religious Practices among the Hijras of India. The SOAS Journal of Graduate Research, 3, 50-67.

Ganzevoort, R. R., van der Laan, M., \& Olsman, E. (2011). Growing up gay and religious. Conflict, dialogue, and religious identity strategies. Mental Health, Religion \& Culture, 14 (3), 209-222.

Garci'a, D. I., Gray-Stanley, J., \& Ramirez-Valles, J. (2008). 'The priest obviously doesn't know that I'm gay': The religious and spiritual journeys of Latino gay men. Journal of Homosexuality, 55 (3), 411-436.

Goh, J. N. (2014). Mary and the Mak Nyahs: Queer Theological Imaginings of Malaysian Maleto-Female Transgendersexuals. Theology \& sexuality, 18 (3), 215-233.

Gurvinder, K. (2012). Hijras: the unique transgender culture of India, International Journal of Culture and Mental Health, 5 (2), 121-126.

Hattie, B., \& Beagan, B. L. (2013). Reconfiguring spirituality and sexual/gender identity: 'It's a feeling of connection to something bigger, it's part of a wholeness.' Journal of Religion \& Spirituality in Social Work: Social Thought, 32 (3), 244-268.

Hidir, R. (2018). LGBT rights protected but must abide by Malaysian laws, says minister. Retrieved from https://www.nst.com.my/news/nation/2018/07/393500/lgbt-rightsprotected-must-abide-malaysian-laws-says-minister.

Honey T. L. E. (2005). Jeffrey Jessie: Recognising Transexuals. Retrieved from http://www.malaysianbar.org.my/gender_issues/jeffrey_jessie_recognising_transexu als_by_honey_tan_lay_ean.html.

Joseph, K. (2018). LGBT or same-sex marriage not for Malaysia, says Dr M. Retrieved from https://www.thestar.com.my/news/nation/2018/09/22/lgbt-or-samesex-marriagenot-for-malaysia-says-dr-m/.

Charan, K. M. (1989). Studies in the Mahabharata. Bhubaneswar: Institute of Orissan Culture. 
Lease, S. H., Horne, S. G., \& Noffsinger-Frazier, N. (2005). Affirming faith experiences and psychological health for Caucasian lesbian, gay, and bisexual individuals. Journal of Counseling Psychology, 52, 378-388.

Lopez Jr., D. (2001). The Story of Buddhism. Harper Collins: New York, NY.

Mageswary, S. S., Asmida, A., Yusnita, M. Y., Nur Fazini, R. S. (2016). Gender Recognition of Transsexuals in Malaysia: Charting the Way Towards Social Inclusion. 3rd Kanita Postgraduate International Conference on Gender Studies. Universiti Sains Malaysia, Penang.

Mathews, M. (nd). Buddhist Impact in the Transgender Lives: A Study of Hunter Reynolds' Brave New Prayers: Rascally Rhetoric to Fan the Flames of Oneness. ELK Asia Pacific Journals-Special Issue.

Nanda, S. (1986). The Hijras of India: Cultural and individual dimensions of an institutionalized third gender role. Journal of Homosexuality, 11, 35-54.

Norafifah, A. H., Azlina, N. A. W., Norajila, C. M., Nazim, M. G. S., Pg Ismali, P. M. (2015). Gejala Transgender di Malaysia: Sorotan Awal Kajian dari Perspektif Islam dan Undang-Undang di Malaysia, Jurnal Penyelidikan Islam.

National Legal Services Authority v. Union of India and Ors., AIR 2014 SC 1863

Pande, A. (2008). Ardhanareshwara. The Androgyne: Rupa Press.

Peach, L. (2002). "Social responsibility, sex change, and salvation: Gender justice in the Lotus Sutra." Philosophy East and West, 52, 50-74

Rodriguez, E. M. (2009). At the intersection of church and gay: A review of the psychological research on gay and lesbian Christians. Journal of Homosexuality, 57(1), 5-38.

Rodriguez, E. M., \& Ouellette, S. C. (2000). Gay and lesbian Christians: Homosexual identity integration in the members and participants of a gay-positive church. Journal for the Scientific Study of Religion, 39 (3), 333-347.

Sakshi, P. (2017). Inclusion of Transgender Community within Socially and Educationally Backward Classes: Examining the Deeper Concerns. Indian Law Institute Law Review, Volume II, 105-123.

Samantha, K. (2014). 8 Influential Malaysian Transgenders You Didn't Know About. Retrieved from https://says.com/my/lifestyle/8-influential-malaysian-transgenders-you-didn-tknow-about.

Sandra, A. W. (2009). Buddhism: Philosophy Beyond Gender. Journal of Chinese Philosophy, 294- 312.

Savinder, K. G., \& Nirmala, D. G. (2010). Understanding Indian Religious Practice in Malaysia. Journal of Social Science, 25 (1-2-3), 135-146.

Scherer, B. (2006). Gender transgender formed and meta-gendered enlightenment: Reading Buddhist narratives as paradigms of inclusiveness. Revista de Estudos da Religião. 3, 6576.

Schnoor, R. F. (2006). Being gay and Jewish: Negotiating intersecting identities. Sociology of Religion, 67 (1), 43-60.

Schuck, K. D., \& Liddle, B. J. (2001). Religious conflicts experienced by lesbian, gay, and bisexual individuals. Journal of Gay and Lesbian Psychotherapy, 5 (2), 63-82.

Shanmuga, K. (2017). Article 121(1A) - what does it really mean? Retrieved from http://www.malaysianbar.org.my/members_opinions_and_comments/article_1211a_ what_does_it_really_mean_.html.

Shuhasyini, B. (2014). Identity Construction of Malaysian Indian Transgender. Journal of Indian Culture and Civilization, 1, 1-11. 
Sumerau, J. E., Mathers, L. A. B., \& Cragun, R. T. (2018). Incorporating Transgender Experience Toward a More Inclusive Gender Lens in the Sociology of Religion. Sociology of Religion: A Quarterly Review, 00:00 1-24.

Syahredzan, J. (2017). The Constitution stands supreme. Retrieved from http://www.malaysianbar.org.my/members_opinions_and_comments/the_constituti on_stands_supreme.html.

Thomson, J. M. (1980). Transsexualism: a legal perspective. Journal of medical ethics, 6, 9297.

Vermeulen, M. (2016). The rise of Rainbow Dharma: Buddhism on sexual diversity and samesex marriage. Conference on Freedom of religion or belief and Sexuality. (Geneva, 8-10 June 2016).

Lama, D., Marianne, D., Alison, A. (1996). Beyond Dogma: Dialogues and Discourses. North Atlantic Books. http://www.e-fatwa.gov.my/fatwa-kebangsaan/pertukaran-jantinadaripada-lelaki-kepada-perempuan.

\section{Corresponding Author}

Hazhari Ismail, Universiti Pendidikan Sultan Idris, Malaysia,

Email: hazhari@fpm.upsi.edu.my

\section{Acknowledgement}

This work is ostensibly supported by a Foundation of IHTIMAM Malaysia. 